\title{
Analisis Faktor-Faktor yang Mempengaruhi Struktur Modal pada Perusahaan Consumer Goods yang Terdaftar Di BEI Tahun 2017-2019
}

\author{
Yenny*, Siti Aisyah Nasution \\ Faculty Of Economy University Prima Indonesia Medan \\ *Correspondence e-mail: yeennny0507@gmail.com, sitiaisyahnasution@unprimdn.ac.id
}

\begin{abstract}
Abstrak. Penelitian ini bertujuan untuk mengkaji dan menganallisis faktor-faktor yang memengaruhi struktur modal perusahaan Consumer Goods yang terdaftar di Bursa Efek Indonesia. Metode pendekatan yang digunaakn adalah pendekatan kuantitatif. Populasi yang akan digunakan adalah yang diambil dari perusahaan manufaktur yang bergerak dibidang Consumer Goods yang terdaaftar di Bursa Efek Indonesia dari tahun 2017-2019. Total jumlah sampel dalam penelitian ini yaitu 87 sampel, yakni: jumlah sampel 29 perusahaan dikalikan dengan 3 periode penelitian. Model penelitian adalah regresi linear berganda. Hasil penelitian ini adalah Profitabilitas, Struktur Aktiva, Ukuran perusahaan, dan Pertumbuhan Penjualan tidak berpengaruh secara parsial dan tidak memiliki nilai terhdap Struktur Modal pada perusahaan sektor Consumer Goods di BEI tahun 2017-2019. Likuiditas berpengaruh negatif secara parsial dan signifikan terhadap Struktur Modal pada perusahaan sektor Consumer Goods di Bursa Efek Indonesia Periode 2017-2019.
\end{abstract}

Kata kunci : Profitabilitas; Likuiditas; Struktur Aktiva; Ukuran perusahaan; Pertumbuhan Penjualan dan Struktur Modal

Abstract. This study aims to examine and analyze the factors that influence the capital structure of consumer goods companies listed on the IDX. The research's method is using quantitative method. The population is taken from manufacturinng companies engaged in consumer goods listed on the IDX from 2017-2019. The total of samples in this study were 87 samples : it is 29 companies multiplied by 3 research periods. The research model is multiple linear regression. The results of this study are Profitability, Asset Structure, Company Size, and Sales Growth partially have no and no significant effect on Capital Structure in Consumer Goods companies on the IDX for the 2017-2019. Liquidity partially has a negative and significant effect on the capital structure of the Consumer Goods sector companies on the Indonesia Stock Exchange for the 2017-2019.

Keywords: Profitability; Liquidity; Asset structure; Company Size; Sales Growth; Capital Structure.

\section{PENDAHULUAN}

Industri/perusahaan sektor barang konsumsi (Consumer Goods) ialah salah satu sektor penting yang menunjang perekonomian Indonesia sebagai negara dengan populasi terbanyak di Asia Tenggara, dengan tingkat konsumsi masyarakat yang juga terus meningkat setiap harinya menjadikan industri Consumer Goods incaran para investor dalam pasar saham yang menjanjikan. Terlebih dimasa pandemi Covid- 19 saat ini, indeks sektor barang konsumsi menguat sebesar $5,46 \%$, hal ini tak terlepas dari banyaknya masyarakat yang melakukan aktivitas dirumah sehingga pembelian bahan konsumsi juga meningkat.

Permasalahan struktur modal merupakan hal penting untuk diperhatikan oleh setiap industri, karena tinggi rendahnya strktur modal perusahaan memengaruhi finansial perusahaan secara langsung. Jika perusahaan lebih memakai sumber dana internal maka akan mengurangi ketergantungan dari pihak luar. Namun jika perusahaan berkembang pesat dan kebutuhan dana juga meningkat, maka pilihan terbaik adalah menggunakan dari pihak eksternal melalui utang atau penerbitan saham baru.

Banyak penelitian telah dilakukan sebelumnya mengenai faktor-faktor yang memengaruhi stuktur modal. Meskipun demikian, masih terdapat ketidakkonsistenan hasil penelitian mengenai variabel yang diteliti yaitu profitabilitas, likuiditas, struktur aktiva, ukuran perusahaan dan pertumbuhan penjualan. Selain itu juga adanya perbedaan antara hasil penelitian terhadap teori struktur modal yang ada.

Sebagai contoh penelitian terdahulu oleh Ni Putu Yeni Astiti (2015), profitabilitas dan struktur aktiva berpengaruh negatif terhadap struktur modal, sedangkan menurut penelitian oleh Putri Ismaida dan Mulia Saputra (2016) profitabilitas dan ukuran perusahaan berpengaruh positif namun pertumbuhan penjualan tak berpengaruh terhadp struktur modal.

\section{Teori Pengaruh Profitabilitas terhadap Struktur Modal}

Menurut Mulyawan (2015), perusahaan dengan tingkat profitabilitas yang tinggi, cenderung memiliki tingkat utang yang rendah, karena perusahaan akan memiliki sumber dana internal yang melimpah.

\section{Teori Pengaruh Likuiditas terhadap Struktur Modal}

Menurut Harahap (2015), semakin besar perbandingan aktiva lancar dengan utang lancar, semakin tinggi pula kemampuan perusahaan untuk menutupi kewajiban jangka pendeknya.

Teori Pengaruh Struktur Aktiva terhadap Struktur Modal 
Yenny dan Siti Aisyah Nasution, Analisis Faktor-Faktor yang Mempengaruhi Struktur Modal pada Perusahaan Consumer Goods yang Terdaftar Di BEI Tahun 2017-2019

Menurut Sitanggang (2013), perusahaan yang memiliki komposisi aktiva tetap berwujud dalam jumlah besar akan memiliki peluang memperoleh tambahan modal melalui utang dengan aktiva tetap yang menjadi jaminan untuk memperoleh utang.

\section{Teori Pengaruh Ukuran Perusahaan terhadap Struktur} Modal

Menurut Mulyawan (2015), semakin besar suatu perusahaan, semakin besar pula tingkat utangnya. Perusahaan kecil kemungkinan memiliki cash inflows yang rendah sehingga tidak mempunyai peluang investasi untuk masuk pasar modal.

\section{Teori Pengaruh Pertumbuhan Penjualan terhadap Struktur Modal}

Menurut Fahmi (2015), semakin besar tingkat pertumbuhan penjualan, maka semakin besar pula utang yang digunakan oleh perusahaan.

\section{METODE}

\section{Jenis dan Sumber Data Penelitian}

Jenis data pada penelitian ini adalah data sekunder. Sumber data diperoleh dari laporan keuangan perusahaan Consumer Goods yang terdaftar di Bursa Efek Indonesia.

\section{Populasi dan Sampel Penelitian \\ Populasi}

Populasi dalam penelitian ini meliputi seluruh perusahaan Consumer Goods yang terdaftar di Bursa Efek Indonesia pada tahun 2017-2019 sejumlah 29 perusahaan.

\section{Sampel}

Teknik pengambilan sampel menggunakan purposive sampling. Kriteria pemilihan sampel dalam penelitian ini adalah sebagai berikut :

1. Perusahaan Consumer Goods yang terdaftar di BEI periode 2017-2019.

2. Perusahaan Consumer Goods yang mempublikasikan laporan keuangan secara berturut-turut selama periode 2017-2019.

3. Perusahaan Consumer Goods yang memiliki laba positif selama periode 2017-2019.

\section{HASIL DAN PEMBAHASAN Hasil Statistik Deskriptif}

Penelitian ini menggunakan sample dari laporan keuangan Consumer Goods yang terdaftar di Bursa Efek Indonesia tahun 2017-2019. Berdasarkan data Profitabilitas, Likuiditas, Struktur Aktiva, Ukuran Perusahaan, Pertumbuhan Penjualan dan Struktur Modal maka dibuat statistik deskriptif yang dapat memberikan gambaran mengenai nilai minimum, nilai maksimum, nilai rata-rata (mean) dan simpangan baku (standar deviasi).
Tabel 1. Hasil Uji Statistik Deskriptif

\begin{tabular}{|c|c|c|c|c|c|}
\hline & $N$ & Kinimum & Moximum & & \\
\hline Profilabiltas & 87 & 001 & 921 & 12666 & 135339 \\
\hline Likuiditas & 87 & .634 & 15,822 & 3,39437 & 2707604 \\
\hline Struktur_aktiva & 87 & .050 & 807 & .42344 & .167127 \\
\hline Ukuran Perusahaan & 87 & 25,796 & 32.201 & 28,91604 & $1.57961:$ \\
\hline Pertumbuhan Penjualan & 87 & 438 & 352 & .07257 & 112168 \\
\hline Struktur_Modal & 87 & 091 & 2,909 &, 65705 &, 537203 \\
\hline Valid N (listwise) & 87 & & & & \\
\hline
\end{tabular}

\section{Uji Asumsi Klasik}

\section{Uji Normalitas}

Dalam penelitian ini, uji statistik menggunakan uji Kolmogorov-Smirnov (K-S) dan analisis grafik menggunakan histogram dan normal P-Plot.

Tabel 2. Hasil Uji Normalitas Uji Kolmogorov-Smirnov
Sebelum Transformasi

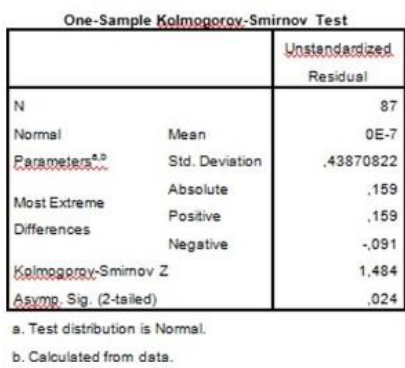

Sumber : Hasil Pengolahan Data SPSS
Setelah Transformasi

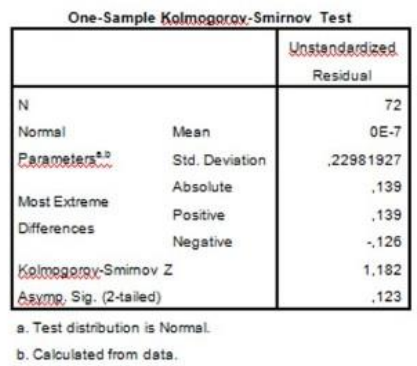

Tabel sebelah kiri menunjukkan hasil uji Kolmogorov-Smirnov dengan nilai signifikan $<0,05$ yaitu 0,024 sehingga dapat disimpulkan hasil uji tidak berdistribusi normal. Tabel sebelah kanan menunjukkan hasil dari uji Kolmogorov- Smirnov setelah ditransformasi dengan nilai signifikan > 0,05 yaitu sebesar 0,123 sehingga dapat disimpulkan hasil uji berdistribusi normal.

Hasil uji normalitas dengan uji histogram dan normal P-Plot adalah sebagai berikut:

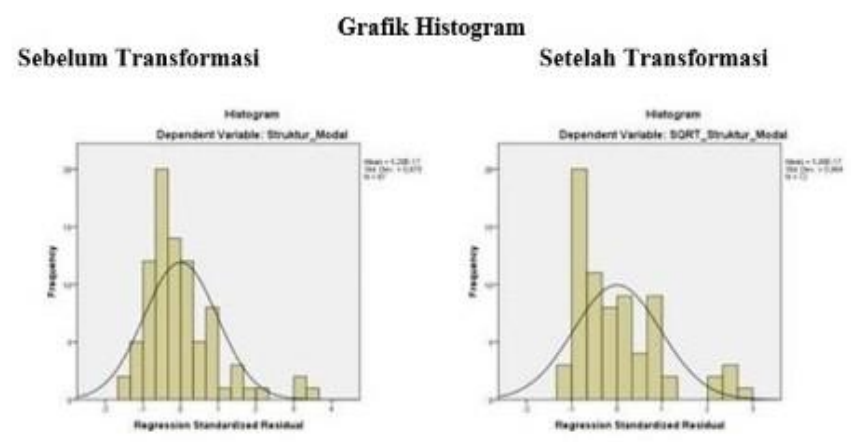

Sumber : Hasil Pengolahan Data SPSS

Gambar 1. Uji Histogram

Gambar sebelah kiri menunjukan data tidak mengikuti bentuk lonceng seperti kurva sehingga jika 
Yenny dan Siti Aisyah Nasution, Analisis Faktor-Faktor yang Mempengaruhi Struktur Modal pada Perusahaan Consumer Goods yang Terdaftar Di BEI Tahun 2017-2019

disimpulkan yaitu grafik tidak berdistribusi normal. Gambar sebelah kanan dapat terlihat bahwa data hampir setara mengikuti kurva berbentuk lonceng. Hal tersebut menunjukkan jika data berdistribusi mendekati normal pada setiap variabel.

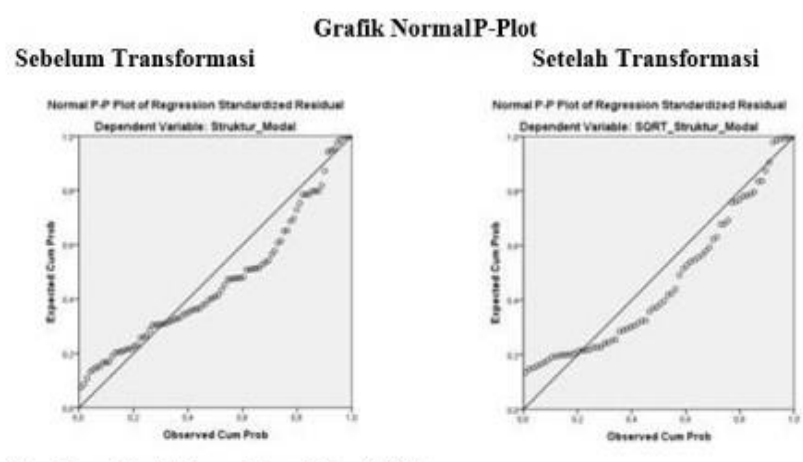

Sumber : Hasil Pengolahan Data SPSS

Gambar 2. Grafik Normal P-Plot

Gambar sebelah kiri menunjukkan titik-titik menyebar tidak mengikuti atau menjauhi garis diagonal sehingga dapat dikatakan data tidak berdistribusi normal. Gambar sebelah kanan menunjukkan titik-titik menyebar mendekati garis diagonal sehingga membuktikan data berdistribusi normal.

\section{Uji Multikolinieritas}

Uji multikolinieritas dapat diukur dengan melihat nilai tolerance dan variance inflation factor (VIF) dengan syarat nilai tolerance $\geq 0,10$ dan nilai VIF $\leq 10$ maka dinyatakan tak terjadi multikolinieritas.

Tabel 3. Uji Multikolinieritas Uji Multikolinieritas Setelah Transformasi

\begin{tabular}{|c|c|c|c|c|c|c|c|}
\hline \multicolumn{8}{|c|}{ Coefficients $^{3}$} \\
\hline \multirow[t]{2}{*}{ Model } & \multicolumn{2}{|c|}{$\begin{array}{l}\text { Unstandardized } \\
\text { Coefficients }\end{array}$} & \multirow{2}{*}{$\begin{array}{c}\begin{array}{c}\text { Standardized } \\
\text { Coefficients }\end{array} \\
\text { Beta }\end{array}$} & \multirow[t]{2}{*}{1} & \multirow[t]{2}{*}{ Sig. } & \multicolumn{2}{|c|}{$\begin{array}{l}\text { Collinearity } \\
\text { Statistics }\end{array}$} \\
\hline & B & Std. Error & & & & Tolerance & VIF \\
\hline (Constant) & 1,974 & 1,173 & & 1,682 & ,097 & & \\
\hline SQRT_Profitabilitas &, 158 &, 209 &, 078 &, 755 & .453 &, 796 & 1,257 \\
\hline SQRT_Likuiditas & -355 &, 058 &,- 758 & $-6,119$ &, 000 &, 551 & 1,816 \\
\hline SQRT_Struktur_Aktiva & -408 &, 243 & -191 & $-1,677$ &, 098 & .653 & 1,531 \\
\hline SQRT_UKuran_Perusahaan & -045 & 203 & -021 & -220 & 827 &, 900 & 1,111 \\
\hline SQRT Pertumbuhan Penjualan & 475 & 268 &, 188 & 1772 & 081 & .751 & 1,332 \\
\hline
\end{tabular}

a. Dependent Variable. SQRT_Struktur_Modal

Sumber : Hasil Pengolahan Data SPSS

Dari tabel tersebut terlihat hasil uji multikolinieritas setelah transformasi dengan nilai tolerance untuk setiap variabel diperoleh $\geq 0,10$ dan nilai $\mathrm{VIF} \leq 10$, maka dinyatakan tidak terjadi multikolinieritas.

\section{Uji Autokorelasi}

Uji autokorelasi dapat diukur dengan uji Durbin Watson dengan syarat du $<\mathrm{d}<4$-du untuk dinyatakan tidak terjadi autokorelasi.
Tabel 3. Uji Autokorelasi

Uji Autokorelasi Setelah Transformasi Model Summary

\begin{tabular}{|c|r|r|r|r|r|}
\hline Model & $R$ & $R$ Square & Adjusted R Square & $\begin{array}{l}\text { Sid. Error of the } \\
\text { Estimate }\end{array}$ & Durbin-Watson \\
\hline 1 &, $665^{*}$ &, 443 &, 401 &, 23837 & 1,998 \\
\hline
\end{tabular}

a. Predictors. (Constant), SQRT_Pertumbuhan_Penjualan, SQRT_Struktur_Aktiva

SQRT_Ukuran_Perusahaan, SQRT_Profitabilitas, SQRT_Likuiditas

b. Dependent Variable. SQRT_St_Modal

Sumber : Hasil Pengolahan Data SPSS

Dari tabel diatas dapat disimpulkan hasil uji Durbin Watson sebesar 1,998 dengan $\mathrm{dl}=1,5422$ dan du $=1,7745$, maka syarat untuk tidak terjadinya autokorelasi telah terpenuhi yaitu $\mathrm{du}<\mathrm{d}<4-\mathrm{du}$; $1,5422<1,998<4-1,7745$;

$1,5422<1,998<2,2255$.

Dengan demikian dapat disimpulkan bahwa pada data tidak terjadi autokorelasi.

\section{Uji Heteroskedastisitas}

Uji heteroskedastisitas dapat diukur dengan melihat grafik Scatterplot dan uji Glejser dengan ketentuan nilai signifikan setiap variable $>0,05$ untuk tidak terjadi heteroskedastisitas.

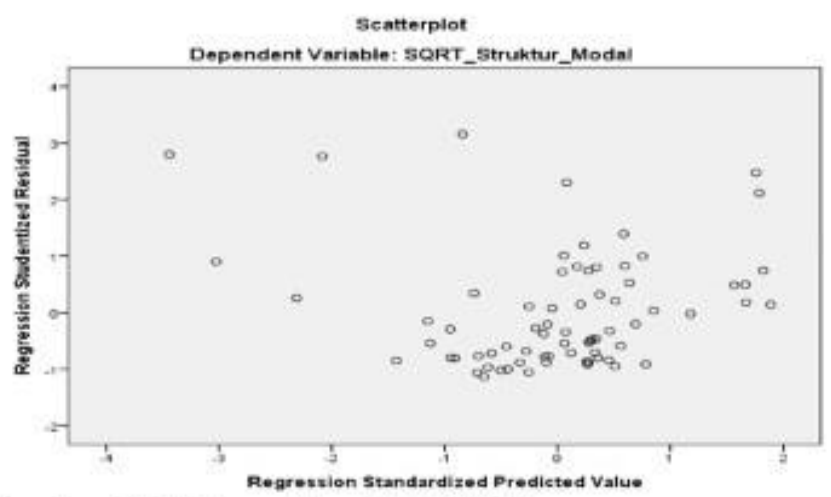

Sumber : Hasil Pengolahan Data SPSS

Gambar 3. Uji Heteroskedastisitas

Dari gambar diatas terlihat bahwa titik-titik tersebar secara acak, hal ini berarti pada sample tak terjadi heteroskedastisitas.

Tabel 4. uji Glejser Uji Glejser Setelah Transformasi

\begin{tabular}{|c|c|c|c|c|c|c|}
\hline \multicolumn{7}{|c|}{ Coefficients" } \\
\hline \multirow{3}{*}{\multicolumn{2}{|c|}{ Model }} & \multirow{2}{*}{\multicolumn{2}{|c|}{$\begin{array}{c}\text { Unstandardized } \\
\text { Coefficients }\end{array}$}} & \multirow{3}{*}{$\begin{array}{c}\begin{array}{c}\text { Standardized } \\
\text { Coefficients }\end{array} \\
\text { Beta } \\
\end{array}$} & \multirow[t]{3}{*}{$t$} & \multirow[t]{3}{*}{ Sig. } \\
\hline & & & & & & \\
\hline & & B & Std Error & & & \\
\hline \multirow{7}{*}{1} & (Constant) & 031 & 665 & & .047 & .963 \\
\hline & SQRT_Profitabilitas & .042 & 119 & .046 & 356 & .723 \\
\hline & SQRT_Likuiditas &, 047 &, 033 & 219 & 1,422 & 160 \\
\hline & SQRT_Struktur Aktiva & -188 & ,138 & -192 & $-1,363$ & .177 \\
\hline & SQRT_Ukuran_Perusahaan &, 036 & ,115 & ,037 & ,311 & .757 \\
\hline & SQRT Pertumbuhan & -051 & 152 & .044 & -337 &, 737 \\
\hline & Penjualan & & & & & \\
\hline
\end{tabular}

a. Dependent Variable: RES2

Sumber : Hasil Pengolahan Data SPSS 
Pada tabel berikut bisa kita lihat bahwa hasil uji Glejser setelah transformasi memiliki nilai signifikan pada setiap variabel $>0,05$ sehingga bisa disimpulkan pada setiap variabel tak terjadi heteroskedastisitas.

\section{Hasil Analisis Data Penelitian Model Penelitian}

Penelitian ini menggunakan analisis regrsi linear berganda untuk menguji hipotesis variabel independen terhadap variabel dependen.

Tabel 5. Analisis Regresi Linear Berganda

\begin{tabular}{|c|c|c|c|c|c|}
\hline \multirow[t]{2}{*}{ Model } & \multicolumn{2}{|c|}{$\begin{array}{c}\text { Unstandardized } \\
\text { Coeflicients }\end{array}$} & \multirow{2}{*}{$\begin{array}{c}\text { Standardized } \\
\text { Coefficients } \\
\text { Beta }\end{array}$} & \multirow[t]{2}{*}{$t$} & \multirow[t]{2}{*}{ Sig } \\
\hline & $B$ & Sld. Error & & & \\
\hline (Constant) & 1,974 & 1,173 & & 1,682 &, 097 \\
\hline SQRT_Profitabilitas &, 158 & 209 &, 078 &, 755 & .453 \\
\hline SQRT_Likuiditas & -355 &, 058 &,- 758 & $-6,119$ &, 000 \\
\hline SQRT_Struktur_Aktiva &,- 408 & 243 & -191 & $-1,677$ &, 090 \\
\hline SQRT Ukuran Perusahaan &,- 045 & 203 &,- 021 &,- 220 & 827 \\
\hline SQRT_Pertumbuhan_Penjualan & -475 & 268 & -188 & $-1,772$ &, 081 \\
\hline
\end{tabular}

a.SQRT Struktur Modal $=1,974+0,158$ SQRT_Profitabilitas - 0,355 SQRT_Likuiditas - 0,408 SQRT_Struktur Aktiva - 0,045 SQRT_Ukuran Perusahaan - 0,475 SQRT_Pertumbuhan Penjualan berikut:

Pernyataan persamaan di atas adalah sebagai

1. Nilai konstanta a sebesar: 1,974 artinya variabel profitabilitas, likuiditas, struktur aktiva, ukuran perusahaan dan pertumbuhan penjualan disebut konstan atau nol, maka struktur modal pada perusahaan Consumer Goods yang terdaftar di Bursa Efek Indonesia tahun 2017-2019 akan mengalami peningkatan sebesar 1,974.

2. Nilai koefisien b1 sebesar: 0,158 artinya setiap peningkatan profitabilitas sebesar 1 satuan, maka pada perusahaan Consumer Goods yang terdaftar di BEI tahun 2017-2019 nilai struktur modal mengalaami peningkatan sebsar 0,158 .

3. Nilai koefisien b2 sebesar $-0,355$ artinya setiap peningkatan likuiditas sebesar 1 satuan, maka pada perusahaan Consumer Goods yang terdaftar di BEI tahun 2017-2019 nilai struktur modal mengalami penurrunan sebesar 0,355 .

4. Nilai koefisien b3 sebesar $-0,408$ artinya setiap peningkatan struktur aktiva sebesar 1 satuan, maka pada perusahaan Consumer Goods yang terdaftar di BEI tahun 2017-2019 nilai struktur modal mengalami penurunan sebesar 0,408 .

5. Nilai koefisien b4 sebesar $-0,045$ artinya setiap peningkatan ukuran perusahaan sebesar 1 satuan, maka pada perusahaan Consumer Goods yang terdaftar di BEI tahun 2017-2019 nilai struktur modal mengalami penurunan sebesar 0,045 .

6. Nilai koefisien b5 sebesar $-0,475$ artinya setiap peningkatan pertumbuhan penjualan sebesar 1 satuan, maka pada perusahaan Consumer Goods yang terdaftar di BEI tahun 2017-2019 nilai struktur modal mengalami penurunan sebesar 0,475 .

\section{Koefisien Determinasi (R2)}

Koefisien determinasi $\left(\mathrm{R}^{2}\right)$ digunakan untuk mengukur sejauh mana kemampuan model dalam hal menerangkan variasi variabel dependen.

Tabel 6. Koefisien Determinasi (R2) Koefisien Determinasi $\left(R^{2}\right)$

\begin{tabular}{|c|r|r|r|r|r|}
\hline Model Summary \\
\hline 1 & \multicolumn{1}{|c|}{$R$} & R Square & Adusted R Square & $\begin{array}{l}\text { Std Error of the } \\
\text { Fstimate }\end{array}$ & Durbin-Walson \\
\hline 1 &, $665^{\circ}$ &, 443 & 401 & 23837 & 1,998 \\
\hline
\end{tabular}

a. Predictors. (Constant), SQRT_Pert_Penjualan, SQRT_SL_AkKlv, SQRT_Ukuran, SQRT_Prot, SQRT_Likuid b. Dependent Variable: SQRT_St_Modal

Sumber : Hasil Pengolahan Data SPSS

Dari tabel diatas diperoleh nilai $\mathrm{R}^{2}$ sebesar 0,401 atau $40 \%$ yang berarti $40 \%$ struktur modal bisa dijelaskan oleh variasi dari kelima variabel independen yaitu profitabilitas, likuiditas, struktur aktiva, ukuran perusahaan dan pertumbuhan penjualan. Sedangkan $60 \%$ dijelaskan oleh faktor-faktor lain yang tidak diteliti.

\section{Pengujian Hipotesis Secara Simultan (Uji F)}

Uji F bertujuan mengukur apakaah semua variabel independen dalam model memiliki pengaruh secara bersama sama terhadap variabel dependen.

Tabel 7. Pengujian Hipotesis Secara Simultan (Uji F) Pengujian Hipotesis Secara Simultan (Uji F)

\begin{tabular}{|c|c|c|c|c|c|c|}
\hline & Model & Sum of Squares & $d f$ & Mean Square & F & Sig. \\
\hline \multirow{3}{*}{1} & Regression & 2,981 & 5 & .596 & 10,492 & $.0000^{\circ}$ \\
\hline & Residual & 3.750 & 66 & .057 & & \\
\hline & Total & 6,731 & 71 & & & \\
\hline
\end{tabular}

a. Dependent Varable: SQRT_Struktur_Modal

b. Predictors: (Constant). SQRT Pertumbuhan_Penjualan, SQRT_Struktur_Aktiva

SQRT_Ukuran_Penusahaan, SQRT_Profitabilitas, SQRT_Likuiditas

Dari tabel diatas dapat dilihat nilai Fhitung > Ftabel $(10,492>2,33)$ dan nilai signifikan $0,000<0,05$, maka profitabilitas, likuiditas, struktur aktiva, ukuran perusahaan dan pertumbuhan penjualan berpengaruh signifikan terhadap struktur modal pada perusahaan Consumer Goods yang terdaftar di Bursa Efek Indonesia periode 2017-2019. 
Yenny dan Siti Aisyah Nasution, Analisis Faktor-Faktor yang Mempengaruhi Struktur Modal pada Perusahaan Consumer Goods yang Terdaftar Di BEI Tahun 2017-2019

\section{Pengujian Hipotesis Secara Parsial (Uji t)}

Uji t digunakan untuk mengukur seberapa jauh pengaruh satu variabel independen secara individual terhadap variabel dependen.

Tabel 8. Pengujian Hipotesis Secara Parsial (Uji t)

\begin{tabular}{|c|c|c|c|c|c|}
\hline \multirow[t]{2}{*}{ Model } & \multicolumn{2}{|c|}{$\begin{array}{l}\text { Unstandardized } \\
\text { Coefficients }\end{array}$} & $\begin{array}{c}\text { Standardized } \\
\text { Coefficients }\end{array}$ & $t$ & Sig. \\
\hline & B & Std Error & Beta & & \\
\hline (Constant) & 1,974 & 1,173 & & 1,662 & 097 \\
\hline SQRT_Profftabilitas & , 158 & 209 & , 078 & ,755 & .453 \\
\hline SQRT_Likuidtas & -355 & ,058 &,- 758 & $-6,119$ & 000 \\
\hline SQRT_Struktur_Aktiva &,- 408 & ,243 & , 191 & $-1,677$ & ,098 \\
\hline SQRT_Ukuran_Perusahaan &,- 045 & ,203 & .021 & .220 & 827 \\
\hline SQRT Pertumbuhan Penjualan & -475 & 268 & -188 & $-1,772$ & 081 \\
\hline
\end{tabular}

Sumber : Hasil Pengolahan Data SPSS

Berdasarkan tabel diatas dapat dijelaskan hasil pengujian secara parsial yaitu:

1. Pengujian hipotesis secara parsial (Uji t) profitabilitas terhadap struktur modal, nilai thitung <ttabel $(0,755<1,98969)$ dan nilai signifikan $0,453>0,05$ maka profitabilitas tidak berpengaruh dan tidak signifikan terhadap struktur modal pada perusahaan Consumer Goods yang terdaftar di BEI tahun 20172019.

2. Pengujian hipotesis secara parsial (Uji t) likuiditas terhadap struktur modal, nilai -thitung <-ttabel ($6,119<-1,98969)$ dan nilai signifikan $0,000<0,05$ maka likuiditas berpengaruh negatif signifikan terhadap struktur modal pada perusahaan Consumer Goods yang terdaftar di BEI tahun 2017-2019.

3. Pengujian hipotesis secara parsial (Uji t) struktur aktiva terhadap struktur modal, nilai -thitung <-ttabel $(-1,677<-1,98969)$ dan nilai signifikan $0,098<0,05$ maka struktur aktiva tidak berpengaruh dan tidak signifikan terhadap struktur modal pada perusahaan Consumer Goods yang terdaftar di BEI tahun 20172019.

4. Pengujian hipotesis secara parsial (Uji t) ukuran perusahaan terhadap struktur modal, nilai -thitung <ttabel $\quad(-0,220<-1,98969)$ dan nilai signifikan $0,827<0,05$ maka ukuran perusahaan tidak berpengaruh dan tidak signifikan terhadap struktur modal pada perusahaan Consumer Goods yang terdaftar di BEI tahun 2017-2019.

5. Pengujian hipotesis secara parsial (Uji t) pertumbuhan penjualan terhadap struktur modal, nilai -thitung <-ttabel $(-1,772<-1,98969)$ dan nilai signifikan $0,081<0,05$ maka pertumbuhan penjualan tidak berpengaruh dan tidak signifikan terhadp struktur modal pada perusahaan Consumer Goods yang terdaftar di BEI tahun 2017-2019.

\section{Pembahasan}

Pengaruh Profitabilitas terhadap Struktur Modal

Dari pengujian hipotesis uji t, profitabilitas tidak berpengaruh dan tidak signifikan terhadap struktur modal. Hasil penelitian ini tidak sejalan dengan teori Mulyawan (2015) dimana perusahaan dengan tingkat profitabilitas yang tinggi, mempunyai tingkat utang yang rendah.

\section{Pengaruh Likuiditas terhadap Struktur Modal}

Dari pengujian hipotesis uji $t$, likuiditas berpengaruh negatif dan signifikan terhadap struktur modal. Hasil penelitian ini sejalan dengan teori Harahap (2015), semakin besar perbandingan aktiva lancar dengan utang lancar, semakin tinggi pula kemampuan perusahaan untuk menutupi kewajiban jangka pendeknya.

\section{Pengaruh Struktur Aktiva terhadap Struktur Modal}

Dari pengujian hipotesis uji t, struktur aktiva tidak berpengaruh dan tidak signifikan terhadap struktur modal. Hasil penelitian ini tidak sejalan dengan teori Sitanggang (2013), perusahaan dengan komposisi aktiva tetap berwujud yang besar memiliki peluang memperoleh tambahan modal melalui utang dengan aktiva tetap sebagai jaminan untuk memperoleh utang.

\section{Pengaruh Ukuran Perusahaan terhadap Struktur Modal}

Dari uji hipotesis uji t, ukuran perusahaan tidak berpengaruh dan tidak signifikan terhadap struktur modal. Hasil penelitian ini tidak sejalan dengan teori Mulyawan (2015), semakin besar suatu perusahaan, semakin besar pula tingkat utangnya.

\section{Pengaruh Pertumbuhan Penjualan terhadap Struktur Modal}

Menurut hasil pengujian hipotesis uji t, pertumbuhan penjualan tidak berpengaruh dan tidak signifikan terhadap struktur modal. Hasil penelitian ini tidak sejalan dengan teori Fahmi (2015), semakin tinggi tingkat pertumbuhan penjualan, maka semakin besar pula utang yang digunakan oleh perusahaan.

\section{SIMPULAN}

Berdasarkan hasil pengujian hipotesis yang telah dilakukan menggunakan program SPSS, peneliti menyimpulkan poin-poin yaitu:

1. Profitabilitas tidak berpengaruh secara parsial dan tidak signifikan terhadap Struktur Modal pada perusahaan sektor Consumer Goods yang terdaftar di BEI tahun 2017-2019.

2. Likuiditas berpengaruh negatif secara parsial dan signifikan terhadap Struktur Modal pada perusahaan Consumer Goods yang terdaftar di Bursa Efek Indonesia periode 2017-2019. 
3. Struktur Aktiva tidak berpengaruh secara parsial dan tidak signifikan terhadap Struktur Modal pada perusahaan Consumer Goods yang terdaftar di BEI tahun 2017-2019.

4. Ukuran Perusahaan tidak berpengaruh secara parsial dan tidak signifikan terhadap Struktur Modal pada perusahaan Consumer Goods yang terdaftar di BEI tahun 2017-2019.

5. Pertumbuhan Penjualan tidak berpengaruh secara parsial dan tidak signifikan terhadap Struktur Modal pada perusahaan Consumer Goods yang terdaftr di BEI tahun 2017-2019.

6. Profitabilitas, Likuiditas, Struktur Aktiva, Ukuran Perusahaan dan Pertumbuhan Penjualan berpengaruh secara simultan terhadap Struktur Modal pada perusahaan Consumer Goods yang terdaftar di BEI tahun 2017-2019.

\section{DAFTAR PUSTAKA}

Astiti, Ni Putu Yeni. 2015. Pengaruh Profitabilitas dan Struktur Asset terhadap Struktur Modal Pada Perusahaan Property And Real Estate yang Terdaftar di Bursa Efek Indonesia. Juima Vol. 5 No. 2. Bali: Universitas Mahasaraswati Denpasar.

Bursa Efek Indonesia. 2020. Laporan Keuangan dan Tahunan. www.idx.co.id.

Fahmi, Irham. 2015. Pengantar Manajemen Keuangan, Teori dan Soal Jawab. Bandung: CV Alfabeta.

Harahap, Sofyan Syafri. 2015. Analisis Kritis atas Laporan Keuangan. Jakarta: PT Raja Grafindo Persada.

Ismaida, Putri dan Mulia Saputra. 2016. Pengaruh Pertumbuhan Penjualan, Profitabilitas, Ukuran, dan Aktivitas Perusahaan terhadap Struktur Modal pada Perusahaan Property dan Real Estate yang Terdaftar di BEI Periode 2012-2014. Jurnal Ilmiah Mahasiswa Ekonomi Akuntansi (JIMEKA) Vol. 1 No. 1. Banda Aceh: Fakultas Ekonomi dan Bisnis Universitas Syiah Kuala.

Mulyawan, Setia. 2015. Manajemen Keuangan. Bandung: Pustaka Setia.

Sitanggang, J.P. 2013. Manajemen Keuangan

Perusahaan Lanjutan. Jakarta: Mitra Wacana

Media. 